\title{
Gambaran Infeksi Nontuberculous Mycobacteria (NTM) pada Penderita Suspek TB Paru Menggunakan Multiplex PCR (MPCR)-Universal Lateral Flow Assay (ULFA) Kit
}

\author{
Putri Wulan Akbar $^{1,2}$, Agustin Iskandar $^{3}$, Tri Wahju Astuti ${ }^{4}$, Kristin Indriana ${ }^{5}$
}

\section{ABSTRAK}

Infeksi paru akibat Nontuberculous Mycobacteria (NTM) dan Mycobacterium tuberculosis (MTB) dapat memberikan gambaran klinis yang serupa sehingga berpotensi menyebabkan kesalahan diagnosis dan terapi. Pemeriksaan Multiplex PCR (MPCR)-Universal Lateral Flow Assay (ULFA) merupakan pemeriksaan berbasis molekuler untuk mendeteksi gen rpoB, IS1660 dan mtp40 yang dapat digunakan untuk membedakan infeksi NTM dari infeksi TB. Tujuan: Mendapatkan gambaran infeksi NTM menggunakan MPCR-ULFA pada penderita terduga TB paru. Metode: Penelitian ini merupakan studi deskriptif dengan pendekatan potong lintang yang dilaksanakan sejak April sampai Juli 2019. Sebanyak 39 sampel sputum dari pasien terduga TB paru dari RSUD Kanjuruhan Kepanjen, Kabupaten Malang diperiksakan apusan BTA, GeneXpert dan MPCR-ULFA. Hasil: Sebanyak 5 sampel (12,8\%) sputum dari pasien terduga TB paru terdeteksi sebagai NTM positif menggunakan pemeriksaan MPCR-ULFA. Empat dari lima sampel (80\%) tersebut memiliki kesesuaian dengan hasil GeneXpert dan apusan BTA, yakni MTB negatif. Pemeriksaan molekuler baik GeneXpert maupun MPCR-ULFA keduanya mendeteksi keberadaan gen rpoB dari Mycobacterium. Metode MPCR-ULFA mengamplifikasi 3 gen target sekaligus (IS1660, mtp40 dan rpoB) sehingga dapat mendeteksi infeksi NTM atau MTB. Simpulan: Prevalensi NTM pada pasien terduga TB paru di RSUD Kanjuruhan Kepanjen menggunakan MPCR-ULFA mencapai 12,8\%. Sebanyak $80 \%$ dari NTM positif memiliki hasil pemeriksaan GeneXpert dan apusan BTA negatif.

Kata kunci: GeneXpert, MPCR-ULFA, NTM, suspek TB paru

\section{ABSTRACT}

Pulmonary infections caused by Nontuberculous Mycobacteria (NTM) and Mycobacterium Tuberculosis (MTB) can show similar clinical manifestations. These could potentially mislead the diagnoses and increase the unnecessary side effects of therapy. Multiplex PCR (MPCR)-Universal Lateral Flow Assay (ULFA) is a molecular-based examination using three genes (rpoB, IS1660 dan mtp40) as a target of amplification. This method could be used to differentiate NTM from TB infections. Objectives: To obtain data of NTM infection in lung TB-suspected patients using MPCRULFA kit. Methods: This research was a descriptive study with cross-sectional design, which was conducted from April-July 2019. A total of 39 sputum samples of patients with suspected pulmonary tuberculosis from RSUD Kanjuruhan, Kepanjen, Malang were required for AFB smear, GeneXpert and MPCR-ULFA tests. Results: Five of 39 samples (12.8\%) of TB suspected the patient showed positive NTM results by MPCR-ULFA. About $80 \%$ of them have negative AFB smear and GeneXpert results. Molecular examinations, both GeneXpert and MPCR-ULFA could detect the presence of the rpoB gene in Mycobacterium. MPCR-ULFA can amplify 3 genes target (IS1660, MTP40 and rpoB) simultaneously, thus can distinguish NTM from MTB infection in one examination. Conclusion: The prevalence of NTM infection in lung TB-suspected patients reaches $12.8 \%$. Of these, $80 \%$ showed a negative result of the GeneXpert and smear microscopy examination.

Keywords: GeneXpert, MPCR-ULFA, NTM, lung TB suspects 
Affiliasi penulis: ${ }^{1}$ Program Pendidikan Dokter Spesialis Patologi Klinik, Fakultas Kedokteran Universitas Brawijaya/RSUD Dr. Saiful Anwar, Malang, Indonesia. ${ }^{2}$ Fakultas Kedokteran dan IImu Kesehatan, Universitas Islam Negeri Maulana Malik Ibrahim, Malang, Indonesia ${ }^{3}$ Dept. Patologi Klinik, Fakultas Kedokteran, Universitas Brawijaya/ RSUD Dr. Saiful Anwar, Malang, Indonesia. ${ }^{4}$ Dept. Pulmonologi, Fakultas Kedokteran, Universitas Brawijaya/RSUD Dr. Saiful Anwar, Malang, Indonesia. ${ }^{5}$ Instalasi Laboratorium RSUD Kanjuruhan Kepanjen, Kabupaten Malang, Indonesia.

Korespondensi: Putri Wulan Akbar, Email: nyirawan@gmail.com Telp: 082233678395

\section{PENDAHULUAN}

Nontuberculous Mycobacteria (NTM) disebut juga sebagai Mycobacteria Other Than Tuberculosis (MOTT) atau Atypical Mycobacteria merupakan semua spesies dalam famili Mycobacterium yang dapat menyebabkan penyakit, selain dari Mycobacterium tuberculosis complex (antara lain: M. tuberculosis, $M$. africanum, M. bovis, M. canettii, M. microti, M. caprae, M. orygis, and M. pinnipedii) dan M. leprae. Genus ini terdiri atas lebih dari 120 spesies dan terdistribusi luas di seluruh dunia dengan variasi patogenisitas, virulensi, daya adaptasi di lingkungan, dan juga respon terhadap pengobatan. ${ }^{1,2}$

NTM merupakan bakteri oportunistik yang banyak ditemukan di air dan tanah. Kuman ini sering menginfeksi pasien yang sudah memiliki penyakit paru sebelumnya, pasien dengan defisiensi imun, maupun pasien dengan penyakit kronis lainnya. ${ }^{2} \mathrm{Di}$ seluruh dunia prevalensi infeksi akibat NTM cenderung mengalami peningkatan. Keberadaan NTM menjadi perhatian setelah terjadinya epidemi AIDS. Di negaranegara maju yang non-endemik TB, infeksi NTM bertanggungjawab atas sebagian besar infeksi Mycobacteria, baik pada individu imunodefisiensi maupun imunokompeten. ${ }^{3} \mathrm{Di}$ negara endemik TB, insidensi dari NTM jarang dilaporkan. Diperkirakan jumlah kasus infeksi NTM di negara endemik TB jauh lebih tinggi. ${ }^{4,5}$ Diagnosis NTM yang seringkali terlewatkan menyebabkan ketidaksesuaian rejimen terapi, biaya pengobatan yang tinggi, dan stigma dari masyarakat yang berpengaruh pada sosio-ekonomi penderita. ${ }^{6}$

Pada praktek klinis, infeksi paru akibat $M$. tuberculosis dan NTM sukar dibedakan. Manifestasi klinis keduanya seringkali mirip dan tumpang tindih.
Infeksi NTM dapat bermanifestasi sebagai bronkopulmoner kronis, limfadenitis, infeksi kulit dan jaringan lunak lainnya. Gejala dari infeksi NTM dapat berupa demam, menggigil, keringat malam, kehilangan berat badan, nyeri abdomen, fatigue, diare, pembesaran kelenjar getah bening, dan anemia. NTM memiliki manifestasi klinis yang mirip, namun regimen terapi NTM berbeda dengan TB. NTM relatif resisten terhadap antibiotik dan dapat menjadi lebih resisten bila diobati dengan satu macam antibiotik saja. Terapi standar NTM meliputi 3-4 macam antibiotik (rifampisin, ethambutol, dan makrolida seperti azithromycin atau clarithromycin) dan berlangsung dalam jangka panjang, yakni 18-24 bulan., ${ }^{2,4,7}$

Penegakan diagnosis dari NTM didasarkan pada keluhan dan gejala klinis pasien, gambaran radiologis baik foto thorax maupun CT scan, dan deteksi spesies NTM melalui kultur dan metode PCR. ${ }^{7}$ Pemeriksaan MPCR-ULFA (Multiplex PCR- Ultra Lateral Flow Assay) merupakan pemeriksaan berbasis molekuler dengan amplifikasi tiga gen target sekaligus (IS1660, mtp40, dan rpoB). Tes ini dapat digunakan untuk mendeteksi keberadaan MTB sekaligus NTM pada pasien dengan dugaan TB paru. Tujuan penelitian ini adalah untuk mendapatkan gambaran infeksi NTM pada pasien terduga TB paru yang diperiksa dengan MPCR-ULFA

\section{METODE}

Penelitian ini merupakan studi deskriptif dengan pendekatan potong-lintang yang dilaksanakan sejak April sampai Juli 2019. Sebanyak 39 sampel sputum dari pasien terduga TB paru di RSUD Kanjuruhan Kepanjen, Kabupaten Malang diperiksakan apusan BTA, GeneXpert dan MPCR-ULFA. Data yang terkumpul selanjutnya diolah secara komputerisasi dan disajikan dalam bentuk tabel distribusi frekuensi.

\section{Prosedur pemeriksaan MPCR-ULFA}

Prosedur pemeriksaan dimulai dengan ekstraksi DNA dari sampel sputum. Sebanyak $5 \mu$ l hasil ekstraksi DNA dicampurkan dengan $15 \mu \mathrm{l}$ master mix yang terdiri atas $10 \mu \mathrm{l}$ primer dan $5 \mu \mathrm{l} 2 \mathrm{X}$ PCR premix. Tabung PCR diputar ke bawah (spinning down) dalam 3 5 detik, kemudian dilakukan amplifikasi dengan alat MPCR. 
Sebanyak $5 \mu$ produk PCR dimasukkan ke dalam sumur periksa pada ULFA Device lalu ditambahkan $50 \mu \mathrm{l}$ running buffer dan $50 \mu \mathrm{l}$ washing buffer.

\section{HASIL}

Hasil pemeriksaan akan muncul dan dibaca dalam 15 menit mengikuti Tabel 1. Data hasil penelitian kemudian ditabulasi dalam tabel distribusi frekuensi.

Tabel 1. Pembacaan hasil MPCR-ULFA

\begin{tabular}{|c|c|}
\hline Hasil & Pita Deteksi \\
\hline \multirow[t]{3}{*}{ TB positif } & $1,2,4,5$ \\
\hline & $1,4,5$ \\
\hline & $2,4,5$ \\
\hline NTM positif & $3,4,5$ \\
\hline Negatif & 4,5 \\
\hline \multirow[t]{2}{*}{ Invalid } & 5 \\
\hline & No band \\
\hline
\end{tabular}

Sebanyak 39 sampel sputum dari pasien terduga TB paru diperiksakan apusan BTA, GeneXpert dan MPCR-ULFA. Distribusi frekuensi jenis kelamin pasien terduga TB paru hampir seimbang, yakni laki-laki $53,85 \%$ dan perempuan $46,15 \%$. Pada usia $>15$ tahun proporsi jumlah terduga paru terdistribusi merata di semua kelompok usia. Data karakteristik pasien dijabarkan pada Tabel 2. Terdapat 10 sampel (25,6\%) dengan apusan BTA positif MTB dan 11 sampel $(28,2 \%)$ dengan GeneXpert positif MTB. Pemeriksaan dengan MPCR-ULFA menunjukkan hasil yang lebih bervariasi, yakni 20 sampel negatif, 13 sampel positif, 5 sampel NTM, dan 1 sampel invalid (Tabel 3). Empat dari lima sampel NTM (80\%) menunjukkan hasil pemeriksaan BTA dan GeneXpert negatif, sedangkan satu sampel memiliki hasil pemeriksaan BTA dan GeneXpert positif. Karakteristik kelima sampel dengan hasil NTM positif dijabarkan di Tabel 4.

Tabel 2. Distribusi frekuensi jenis dan usia pasien terduga TB paru

\begin{tabular}{|c|c|c|}
\hline \multicolumn{2}{|c|}{ Karakteristik } & $n=39$ \\
\hline \multirow[t]{2}{*}{ Jenis kelamin } & Laki-Laki & $21(53,85 \%)$ \\
\hline & Perempuan & $18(46,15 \%)$ \\
\hline \multirow[t]{5}{*}{ Usia } & $<15$ tahun & $1 \quad(2,6 \%)$ \\
\hline & $15-30$ tahun & $9(23,1 \%)$ \\
\hline & $31-45$ tahun & $8 \quad(20,5 \%)$ \\
\hline & $46-60$ tahun & $10(25,6 \%)$ \\
\hline & $>60$ tahun & $11(28,2 \%)$ \\
\hline Median Usia & $51(26-62)$ tahun & \\
\hline
\end{tabular}


Tabel 3. Hasil pemeriksaan sputum pasien terduga TB paru

\begin{tabular}{|c|c|c|c|c|c|c|c|c|c|c|}
\hline \multirow{3}{*}{\multicolumn{2}{|c|}{ Pemeriksaan BTA }} & \multirow{3}{*}{ Jumlah } & \multicolumn{4}{|c|}{ GeneXpert } & \multicolumn{4}{|c|}{ MPCR-ULFA } \\
\hline & & & \multicolumn{3}{|c|}{ Positif (28,2\%) } & \multirow{2}{*}{$\begin{array}{l}\text { Negatif } \\
(71,8 \%)\end{array}$} & \multicolumn{2}{|c|}{ Positif (46,2\%) } & \multirow{2}{*}{$\begin{array}{l}\text { Negatif } \\
(51,3 \%)\end{array}$} & \multirow{2}{*}{$\begin{array}{l}\text { Invalid } \\
(2,5 \%)\end{array}$} \\
\hline & & & Low & Med. & High & & MTB & NTM & & \\
\hline Positif & + & 1 & 1 & 0 & 0 & 0 & 0 & 1 & 0 & 0 \\
\hline \multirow[t]{2}{*}{$(25,6 \%)$} & ++ & 1 & 0 & 1 & 0 & 0 & 0 & 0 & 1 & 0 \\
\hline & +++ & 8 & 0 & 3 & 5 & 0 & 8 & 0 & 0 & 0 \\
\hline $\begin{array}{l}\text { Negatif } \\
(74,4 \%)\end{array}$ & & 29 & 1 & 0 & 0 & 28 & 5 & 4 & 19 & 1 \\
\hline Total & & $n=39$ & 2 & 4 & 5 & 28 & 13 & 5 & 20 & 1 \\
\hline
\end{tabular}

Tabel 4. Karakteristik pasien dengan hasil NTM pada pemeriksaan dengan MPCR-ULFA

\begin{tabular}{cccccc}
\hline No. & Usia (tahun) & $\begin{array}{c}\text { Jenis } \\
\text { Kelamin }\end{array}$ & $\begin{array}{c}\text { BTA } \\
\text { mikroskopis }\end{array}$ & GeneXpert & $\begin{array}{c}\text { Karakteristik } \\
\text { sputum }\end{array}$ \\
\hline 1 & 62 & Laki-laki & Negatif & Negatif & Mucous \\
2 & 44 & Laki-laki & Negatif & Negatif & Mucous \\
3 & 12 & Perempuan & $1+$ & Low & Mucous \\
4 & 42 & Laki-laki & Negatif & Negatif & Mucous \\
5 & 31 & Perempuan & Negatif & Negatif & Mucous \\
\hline
\end{tabular}

\section{PEMBAHASAN}

Jumlah infeksi akibat NTM cenderung mengalami peningkatan. Pasien dengan gangguan struktural paru, seperti: bronchiektasis, PPOK, kistik fibrosis, dan asma memiliki risiko yang lebih besar untuk terinfeksi NTM. Lebih dari $90 \%$ pasien dengan bronchiektasis memiliki infeksi NTM aktif saat terdiagnosis. Pasien dengan usia diatas 50 tahun, pasien dengan gangguan imun, serta pasien dengan respon terapi antibiotik yang rendah merupakan kelompok yang rentan terinfeksi $\mathrm{NTM}^{8}$ Identifikasi Mycobacteria penting untuk menentukan antibiotik empiris yang diberikan dan mencegah pemberian obat-obatan yang tidak diperlukan untuk pasien. ${ }^{2,9}$

Infeksi akibat NTM seringkali terkamuflase dengan infeksi yang diakibatkan oleh $M$. tuberculosis (MTB). Diagnosis Multidrug Resistant Tuberculosis (MDR-TB) dilaporkan bias dengan diagnosis dari NTM pada lebih dari $11 \%$ kasus. $^{10}$ Kasus infeksi TB dan NTM dapat memberikan gambaran klinis yang serupa. Keduanya dapat mengeluhkan gejala serupa berupa batuk berdahak selama 2-3 minggu atau lebih, sesak nafas, badan lemas, nafsu makan menurun, berat badan menurun, malaise, berkeringat malam hari tanpa kegiatan fisik, demam meriang lebih dari satu bulan. Dalam situasi tersebut pemeriksaan laboratorium dan mikrobiologi dapat bermanfaat untuk membedakan infeksi MTB dengan NTM., ${ }^{7,9,11}$

Pemeriksaan mikrobiologi konvensional dengan teknik hapusan memiliki tingkat sensitivitas yang rendah, sedangkan kultur memerlukan waktu yang panjang. ${ }^{12}$ Teknik pemeriksaan berbasis molekuler berkembang pesat dalam diagnosis Mycobacterium. Teknik ini terbukti lebih cepat dengan tingkat sensitivitas tinggi. ${ }^{13}$ Pemeriksaan dengan multipleks PCR menggunakan tiga primer spesifik untuk meningkatkan kemampuan deteksi MTB dan NTM. ${ }^{14}$ Sensitivitas dan spesifitas dari MPCR mencapai $91,9 \%$ dan $88,4 \%{ }^{8}$

Sebanyak lima dari 39 (12,8\%) sampel sputum pasien terduga paru terdeteksi sebagai NTM melalui pemeriksaan MPCR-ULFA. Pemeriksaan dengan MPCR-ULFA mengamplifikasi tiga gen target, yakni IS6110 (pita 1), mtp40 (pita 2), dan rpo-B (pita 3). Pemeriksaan ini merupakan pemeriksaan kualitatif dengan tiga tahapan utama. Tahap pertama adalah ekstraksi DNA, dilanjutkan dengan amplifikasi gen menggunakan multipleks PCR, dan pembacaan hasil hibridisasi DNA pada pita membran nitroselulosa. ${ }^{15}$ Gen rpo- $B$ yang terletak di pita nomor 3 pada alat ULFA merupakan penanda umum untuk bakteri 
Mycobacterium, sedangkan gen IS6110 dan mtp40 keduanya spesifik untuk MTB. Sekuens insersi IS6110 merupakan target yang paling umum digunakan dalam deteksi MTB. Sedangkan gen rpo- $B$ juga menjadi target pemeriksaan GeneXpert dalam mendeteksi resistensi MTB terhadap rifampisin. $8,13,16$

Hasil studi ini menunjukkan bahwa 4 dari 5 sampel $(80 \%)$ yang terdeteksi NTM dengan MPCRULFA memiliki kesesuaian dengan hasil GeneXpert dan apusan BTA, dimana keduanya menunjukkan hasil negatif MTB. Pemeriksaan Tes Cepat Molekuler (TCM) dengan GeneXpert merupakan metode berbasis nested real-time PCR yang digunakan secara luas untuk mendeteksi keberadaan MTB beserta sensitifitasnya terhadap rifampisin. $^{17}$ Primer PCR mengamplifikasi sekitar $81 \mathrm{bp}$ daerah inti gen rpoB yang mengkode sub unit $\beta$ dari polimerase RNA pada kompleks MTB. Beberapa studi menunjukkan bahwa pemeriksaan GeneXpert memiliki performa yang baik dalam membedakan MTB dengan NTM pada load bakteri yang rendah. ${ }^{11,16}$

Hasil pemeriksaan negatif MTB (MTB not detected) dari GeneXpert tidak dapat membedakan negatif Mycobacteria (MTB maupun NTM) dengan positif NTM. Pada hasil studi ini didapatkan satu sampel positif NTM yang memiliki hasil apusan BTA dan GeneXpert positif. Pang et al. menguji kemampuan GeneXpert dalam mengidentifikasi NTM dengan dilusi serial dari jumlah/load bakteri $\left(10^{8}, 10^{6}\right.$, $10^{4}$, dan $\left.10^{2} \mathrm{CFU} / \mathrm{mL}\right)$. Hasil studi tersebut menunjukkan bahwa pada load bakteri $10^{6}$, sebanyak 5 dari 12 spesies NTM teridentifikasi sebagai MTB positif dengan GeneXpert. Dua spesies yakni $M$. abscessus dan $M$. smegmatis, ditandai oleh GeneXpert sebagai MTB dengan Rifampicin resisten. Hasil penelitian tersebut menunjukkan bahwa pada load bakteri yang tinggi, GeneXpert dapat salah mengidentifikasi spesies NTM sebagai MTB sehingga menghasilkan positif palsu. Kemampuan deteksi GeneXpert paling akurat didapatkan pada load bakteri $10^{2}{ }^{11}$

Hipotesis lain menyebutkan bahwa gen rpo- $B$ pada Mycobacterium merupakan gen penjaga dengan sedikit keragaman genetik (conserved gene). Tingginya konservasi pada gen ini diperkirakan mengurangi spesifitas deteksi GeneXpert, terutama pada load bakteri yang tinggi. ${ }^{18,19}$ Teknik pemeriksaan konvensional seperti hapusan memiliki sensitivitas yang variatif. Pemeriksaan ini sangat dipengaruhi oleh keterampilan dari pemeriksa dan tidak dapat digunakan untuk membedakan NTM dengan MTB. ${ }^{20}$ Penelitian dari Raveendran dan Wattal menunjukkan bahwa hasil kultur 6 sampel dengan hasil PCR negatif dan mikrobiologis positif didapatkan sebanyak dua sampel tumbuh sebagai NTM dan empat sisanya tumbuh MTB. ${ }^{15}$

\section{SIMPULAN}

Prevalensi NTM pada pasien terduga TB paru di RSUD Kanjuruhan Kepanjen menggunakan MPCRULFA mencapai 12,8\%. Dari jumlah tersebut sebanyak empat sampel $(80 \%)$ diantaranya memiliki kesesuaian hasil dengan pemeriksaan GeneXpert dan apusan BTA.

\section{SARAN}

Penelitian ini menggunakan bahan biologi tersimpan berupa sampel sputum pasien terduga TB sehingga tidak mencakup data klinis pasien. Diharapkan ke depan terdapat penelitian lanjutan dengan data klinis pasien dan penambahan pemeriksaan kultur sputum.

\section{UCAPAN TERIMA KASIH}

Terima kasih kepada Youngkil Park selaku manajer dari KOICA TB project. Penelitian ini merupakan hasil kerjasama dengan KOICA (Korea International Cooperation Agency) melalui program Creative Technology Solution (CTS).

\section{DAFTAR PUSTAKA}

1. Henkle E, Aksamit T, Barker A, Daley CL, Griffith $D$, Leitman $P$, et al. Patient-centered research priorities for pulmonary nontuberculous mycobacteria (NTM) infection an NTM research consortium workshop report. Ann Am Thorac Soc. 2016;13(9):S379-84.

2. Kumar Gupta P, Gupta K, Rana R, Bhandarkar A. Pulmonary Tuberculosis Versus Pulmonary Non-Tuberculous Mycobacterial Infection. Journal, Indian Acad Clin Med I. 2018;19(1). 
3. Gopinath K, Singh S. Non-Tuberculous mycobacteria in TB-endemic countries: Are we neglecting the danger? PLoS Negl Trop Dis. 2010;4(4):1-5.

4. Das S, Garg T, Chopra S, Dasgupta A. Nontuberculous mycobacteria: An update on infections caused, laboratory identification and their treatment. Infect Dis and Your Heal. 2018;1(1):225-38.

5. Kim SY, Shin SH, Moon SM, Yang B, Kim H, Kwon OJ, et al. Distribution and clinical significance of Mycobacterium avium complex species isolated from respiratory specimens. Diagn Microbiol Infect Dis. 2017;88(2):125-37.

6. Shahraki $\mathrm{AH}$, Heidarieh $\mathrm{P}$, Bostanabad SZ, Khosravi AD, Hashemzadeh M, Khandan S, et al. "Multidrug-resistant tuberculosis" may be nontuberculous mycobacteria. Eur J Intern Med. 2015;26(4):279-84.

7. Singhal R, Myneedu VP. Microscopy as a diagnostic tool in pulmonary tuberculosis. Int $\mathrm{J}$ Mycobacteriology. 2015;4(1):1-6.

8. Loukil A, Kirtania P, Bedotto M, Drancourt M. FISHing mycobacterium tuberculosis complex by use of a rpoB DNA Probe Bait. J Clin Microbiol. 2018;56(10):1-8.

9. Brode SK, Daley CL, Marras TK. The epidemiologic relationship between tuberculosis and nontuberculous mycobacterial disease: A systematic review. Int $\mathrm{J}$ Tuberc Lung Dis. 2014;18(11):1370-7.

10. Sali M, De Maio F, Caccuri F, Campilongo F, Sanguinetti M, Fiorentini $S$, et al. Multicenter evaluation of anyplex plus MTB/NTM MDR-TB assay for rapid detection of mycobacterium tuberculosis complex and multidrug-resistant isolates in pulmonary and extrapulmonary specimens. J Clin Microbiol. 2016;54(1):59-63.

11. Pang $Y$, Lu J, Su B, Zheng $H$, Zhao $Y$. Misdiagnosis of tuberculosis associated with some species of nontuberculous mycobacteria by GeneXpert MTB/RIF assay. Infection. 2017; 45 (5):677-81.

12. Pfuetze $\mathrm{KH}$, Hubble $\mathrm{R}$, Henkle $\mathrm{E}$, Aksamit $\mathrm{T}$, Barker A, Daley CL, et al. Microscopy as a diagnostic tool in pulmonary tuberculosis. J Clin Microbiol. 2016;4(1):1370-7.

13. Andre E, Goeminne L, Cabibbe A, Beckert $P$, Kabamba Mukadi B, Mathys V, et al. Consensus numbering system for the rifampicin resistanceassociated rpoB gene mutations in pathogenic mycobacteria. Clin Microbiol Infect. 2017; 23 (3): 167-72.

14. Mokaddas E, Ahmad S. Development and evaluation of a multiplex PCR for rapid detection and differentiation of Mycobacterium tuberculosis complex members from non-tuberculous mycobacteria. Jpn J Infect Dis. 2007; 60 (2-3): 140-4.

15. Raveendran R, Wattal C. Utility of multiplex realtime PCR in the diagnosis of extrapulmonary tuberculosis. Brazilian J Infect Dis [Internet]. 2016;20(3):235-41. Available from: http://dx.doi.org/10.1016/j.bjid.2016.01.006

16. Moure R, Muñoz L, Torres M, Santin M, Martín $R$, Alcaide F. Rapid detection of Mycobacterium tuberculosis complex and rifampin resistance in smear-negative clinical samples by use of an integrated real-time PCR method. J Clin Microbiol. 2011;49(3):1137-9.

17. Piatek AS, Van Cleeff $M$, Alexander $H$, Coggin WL, Rehr M, Van Kampen S, et al. GeneXpert for TB diagnosis: Planned and purposeful implementation. Glob Heal Sci Pract. 2013; 1 (1): 18-23.

18. Maruthai K, Ravibalan T, Vallayyachari K, Kesavan S, Samrot A V, Muthaiah M. Molecular typing and differentiation of Mycobacterium tuberculosis clinical isolates using Double Repetitive Element PCR and Duplex PCR. Int J Mycobacteriology. 2015;4(1):60-6.

19. Tang TH, Ahmed SA, Musa M, Zainuddin ZF. Rapid detection of Mycobacterium tuberculosis in clinical samples by multiplex polymerase chain reaction (mPCR). World J Microbiol Biotechnol. 2013;29(12):2389-95.

20. Tadesse M, Aragaw D, Rigouts L, Abebe G. Increased detection of smear-negative pulmonary tuberculosis by GeneXpert MTB/RIF® assay after bleach concentration. Int $\mathrm{J}$ Mycobacteriology. 2016;5(2):211-8. 